University of Florida Levin College of Law

UF Law Scholarship Repository

UF Law Faculty Publications

Faculty Scholarship

2018

\title{
Of Power and Process: Handling Harassers in an At-Will World
}

Rachel Arnow-Richman

University of Florida Levin College of Law, rarnowrichman@law.ufl.edu

Follow this and additional works at: https://scholarship.law.ufl.edu/facultypub

Part of the Labor and Employment Law Commons

Recommended Citation

Rachel Arnow-Richman, Of Power and Process: Handling Harassers in an At-Will World, 128 Yale L.J. Forum 85 (2018)

This Article is brought to you for free and open access by the Faculty Scholarship at UF Law Scholarship Repository. It has been accepted for inclusion in UF Law Faculty Publications by an authorized administrator of UF Law Scholarship Repository. For more information, please contact kaleita@law.ufl.edu. 
THE YALE LAW JOURNAL FORUM

JUNE 18,2018

\title{
Of Power and Process: Handling Harassers in an At- Will World
}

\author{
Rachel Arnow-Richman
}

A B S T RACT. In the wake of the \#MeToo movement, companies have taken swift and severe disciplinary action against alleged harassers, raising questions in some instances as to whether their responses were justified. This Essay argues that balancing the goals of the \#MeToo movement with principles of fairness to the accused demands attention to an overlooked aspect of the problem: the employment status of the alleged harasser. The background rule of employment at will, coupled with employer contracting practices and the law of sexual harassment itself, produces a world in which employers are inclined to tolerate sexual harassment and other misconduct by top-level employees, but aggressively police "inappropriate" behavior by the rank-and-file. This Essay concludes that changing this calculus will require abandoning long-standing contracting practices that protect top-level employees and adopting collective bargaining-style protocols for dealing with vulnerable workers accused of harassment.

\section{INTRODUCTION}

In November 2017, in the wake of the Harvey Weinstein scandal, Minnesota Public Radio (MPR) announced that it was severing ties with radio personality Garrison Keillor based on "allegations of his inappropriate behavior." ${ }^{1}$ According to Keillor, he inadvertently placed a hand on an employee's bare back while

1. Angie Andresen, Statement from Minnesota Public Radio Regarding Garrison Keillor and a Prairie Home Companion, Minn. PUB. RADIO (Nov. 29, 2017), http://www.mpr.org/stories/2017 /11/29/statement-from-minnesota-public-radio-regarding-garrison-keillor-and-a-prairie -home-compa [https://perma.cc/76AH-UYCB]. 
trying to console her. ${ }^{2}$ Public indignation at the firing followed. Within days, MPR had received thousands of comments from the entertainer's fan base objecting to its decision. ${ }^{3}$ MPR, according to listeners, had come down too hard for too little.

As with so many of the stories born of the \#MeToo movement, however, more was to come. Subsequent press coverage revealed an eleven-year history of questionable behavior, including sexual remarks, alleged age and gender discrimination, and an offer of a confidential settlement following a soured relationship with a subordinate. ${ }^{4}$ Such revelations, like the even more egregious examples exposed over the six months that followed, land a one-two punch: as shocking as the behavior is the fact that it was tolerated for so long.

It is too soon to predict the legacy of the \#MeToo movement, but the story of Keillor's fall suggests two very different possibilities. It confirms what appears to be the dominant response: public opinion has overwhelmingly supported victims and condemned perpetrators. Onlookers are by now familiar with the recurring media cycle in which a single accusation of "sexual misconduct" against a well-known figure spurs initial denial and outrage, only to be followed by a larger media reveal.

But there is also an undercurrent of concern. Some commentators have questioned whether accused harassers are receiving "due process" and expressed fear that trivial or benign sexualized behavior will get swept up in the mix. ${ }^{5}$ Employers may feel they have little choice in handling employee complaints. With harassment in the spotlight, many are likely to conclude that a swift and severe response to any allegation of misconduct is the only way to avoid a public relations nightmare. ${ }^{6}$

2. Laura Yuen et al., Investigation: For Some Who Lived in It, Keillor's World Wasn't Funny, MPR News (Jan. 23, 2018, 5:25 PM), https://www.mprnews.org/story/2018/o1/23/keillor -workplace [https://perma.cc/QY7K-UK77].

3. Garrison Keillor, Garrison's Response to Jon McTaggrt's Letter of Jan. 23, 2018, GARRISON KeILLOR (Feb. 4, 2018), http://www.garrisonkeillor.com/writing [https://perma.cc/5PKDKWVM]; Yuen et al., supra note 2.

4. Yuen et al., supra note 2.

5. Valeriya Safronova, Catherine Deneuve and Others Denounce the \#MeToo Movement, N.Y. TIMES (Jan. 9, 2018), http://www.nytimes.com/2018/o1/og/movies/catherine-deneuve-and -others-denounce-the-metoo-movement.html [https://perma.cc/WP4F-PCF2]; Shira A. Scheindlin \& Joel Cohen, After \#MeToo, We Can't Decide to Ditch Due Process, Guardian (Jan. 8, 2018, 6:00 AM), http://www.theguardian.com/commentisfree/2018/jan/o8/metoo-due -process-televictions [https://perma.cc/WB7M-DHMR].

6. Elizabeth Chuck, Accusations in the \#MeToo Era: How Companies Handle Complaints, NBC News (Dec. 17, 2017, 8:27 AM), http://www.nbcnews.com/storyline/sexual-misconduct /accusations-metoo-era-how-companies-handle-complaints-n829326 [https://perma.cc /MP8A-CTV8]. 
This Essay argues that balancing the goals of the \#MeToo movement with principles of fairness demands attention to an overlooked aspect of the problem: the employment status of the accused. The background rule of employment at will, coupled with employer-contracting practices and the law of sexual harassment itself, produces a world in which employers are inclined to tolerate sexual harassment and other misconduct by top-level employees but aggressively police "inappropriate" behavior by the rank-and-file. While the former have the market power to negotiate job security and other contractual protections, the latter are almost invariably at-will employees who have no legal recourse against job loss or disproportionate discipline. Faced not only with the risk of sexual-harassment liability, but now with potential damage to their image and brand, companies have little to lose in taking a hard line against the most vulnerable workers.

In sum, both \#MeToo reformers and the movement's skeptics are correct: when it comes to accusations of sexual harassment, we need greater institutional accountability for the conduct of those at the top of the workplace hierarchy, alongside greater protection for the rank-and-file. This Essay considers why that is and how it might be achieved.

Part I explains how the dominant account of sexual harassment ignores the roles of gender and power-oversights that pave the way for a misdirected corporate response that indiscriminately targets sexualized behavior rather than sex-based harassment. Part II uncovers how background law and private ordering by employers enable recurring sexual harassment by high-level actors but leave ordinary workers vulnerable to disproportionate discipline. Part III offers preliminary suggestions for an appropriate organizational approach to handling accusations of harassment. Companies must put a firm stop to exploitive sexbased behavior while taking a nuanced approach to sexualized behavior generally. This requires abandoning long-standing contracting practices that protect top-level employees and adopting collective-bargaining-style protocols for dealing with vulnerable workers accused of harassment.

\section{SEXUAL HARASSMENT AS AN EXTENSION OF EMPLOYER POWER}

Determining how to appropriately handle accusations of sexual harassment requires an understanding of the underlying wrong. The \#MeToo movement, like the discussion of sexual harassment historically, has focused almost exclusively on unwanted sexualized behavior. ${ }^{7}$ This both misunderstands the harm of sexual harassment and overlooks its context. Sexual harassment is an expression of gender discrimination enabled by workplace power dynamics - dynamics that

7. Vicki Schultz, Reconceptualizing Sexual Harassment, Again, 128 YALE L.J.F. 22, 33-34 (2018) [hereinafter Schultz, Reconceptualizing Again]. 
derive in part from the absence of legal protection for vulnerable workers. The top dogs of the work world are uniquely positioned to perpetrate harassment, while the workers below them face the risk of ill-founded accusations of harassment and are defenseless against any employer response.

In her seminal work, Professor Vicki Schultz argues that sexual harassment has become unmoored from gender-equality principles. ${ }^{8}$ She reminds us that sexual harassment is a form of sex discrimination: its purpose and effect is to call attention to women's differences, implicitly undermining their capacity as workers while asserting and preserving male privilege and status. ${ }^{9}$ Sexual harassment may express itself in sexualized language or behavior or it may take the form of nonsexualized hostility toward workers of either sex who fail to conform to prescribed gender norms. ${ }^{10}$ This makes sexual desire a poor proxy for the problem. Efforts to eliminate workplace sexuality are underinclusive because they fail to capture nonsexualized forms of sexual harassment. ${ }^{11}$ They are also likely to be overinclusive in that they fail to distinguish between discriminatory and innocuous - sometimes, even welcome-sexualized behavior. ${ }^{12}$

Schultz's classic account of what is wrong with standard sexual harassment discourse is correct. But, as she acknowledges in her contribution to this Collection, it is also incomplete. ${ }^{13}$ The popular conception of sexual harassment not only ignores discrimination as a central element of sexual harassment, it also disregards the inherent power dynamics of the typical employment environment. To be sure, the composition and structure of many workplaces reflect longstanding discrimination - as the \#MeToo movement lays bare, the highest ranked positions in many industries are held by men who assert power in discriminatory ways, whether through sexualized or other forms of harassment, against women in subordinate positions. ${ }^{14}$ But the ability to mistreat workers of

8. See Vicki Schultz, Reconceptualizing Sexual Harassment, 107 YALE L.J. 1683 (1998) [hereinafter Schultz, Reconceptualizing]; Vicki Schultz, The Sanitized Workplace, 112 YALE L.J. 2061 (2003) [hereinafter Schultz, Sanitized Workplace].

9. Schultz, Reconceptualizing, supra note 8, at 1699-1702; Schultz, Sanitized Workplace, supra note 8, at 2079-87.

10. Schultz, Reconceptualizing, supra note 8, at 1756-61, 1774-89; Schultz, Sanitized Workplace, supra note 8, at 2065-66. For an excellent account of how gender norm conformity undergirds sexual harassment, see Brian Soucek, Queering Sexual Harassment Law, 128 YALE L.J.F. 67, 7376(2018) (using narrative and queer theory to juxtapose desire-based and gender-based harassment in the context of sexual harassment of a lesbian firefighter).

11. Schultz, Reconceptualizing, supra note 8, at 1729-33.

12. Schultz, Sanitized Workplace, supra note 8, at 2082-87.

13. Schultz, Reconceptualizing Again, supra note 7, at 52-53.

14. Id. 
either sex by any means is a consequence of the general allocation of workplace rights - an allocation that derives from employment at will.

American law presumes that both the employer and the employee are free to terminate their relationship at any time for any reason or no reason at all. ${ }^{15}$ This default rule, combined with the absence of robust public regulation of workplace relationships, means that terms of employment are determined almost entirely by private ordering. ${ }^{16}$ Consequently, most workers, other than those at the very top of the workplace hierarchy, have no right to their job, nor any voice in dictating the conditions of their employment. ${ }^{17}$ They are vulnerable not only to harassment, but also to loss of work, demotions, relocations, transfers, pay cuts, reductions in hours, mandatory overtime, oppressive schedules - the full range of adverse changes to their working lives and job conditions. ${ }^{18}$ In contrast, toplevel employees are able to exert superior market power to obtain job security as well as binding and desirable employment terms. The resulting power disparity means that the highest-level workers are free to impose outrageous demands on subordinate employees, subject them to verbal abuse, threaten their livelihoods, disrupt their career trajectories - in short, to create a hostile work environment.

Antidiscrimination law, in theory, constrains private ordering by offering victims a cause of action for sexual harassment, sex discrimination, and retaliation. However, the prospect of a lawsuit historically has not been enough to alter

15. For a discussion of employment at will, its scope, and its history, see Rachel Arnow-Richman, Mainstreaming Employment Contract Law: The Common Law Case for Reasonable Notice of Termination, 66 FLA. L. REV. 1513, 1530-45 (2014); Richard A. Bales, Explaining the Spread of Atwill Employment as an Interjurisdictional Race to the Bottom of Employment Standards, 75 TENN. L. ReV. 453, 460-66 (2008); Jay M. Feinman, The Development of the Employment at Will Rule, 20 AM. J. LegAl Hist. 118, 120 (1976).

16. For a general discussion of the concept of private ordering and its various forms, see Steven L. Schwarcz, Private Ordering, 97 Nw. U. L. ReV. 319, 324-29 (2002) (describing a rulemaking spectrum with soveriegn control at one end and unregulated private action at the other).

17. Cynthia Estlund, Truth, Lies, and Power at Work, 101 MinN. L. Rev. HeADNOTES 349, 360 (2017) (noting that "both exit and voice are costly and constrained for workers," resulting in employers maintaining significant power over employees).

18. See generally Elizabeth Anderson, Private Government: How Employers Rule Our LIVES 37-41 (2017) (analogizing the at-will workplace to a communist dictatorship); Nantiya Ruan, Corporate Masters \& Low-Wage Servants: The Social Control of Workers in Poverty, 24 WASH. \& LEE J. CIV. RTS. \& SOC. JUST. 103, 136-47 (2017) (describing the precariousness of low-wage work and employees' vulnerability to objectionable working conditions). Employers can leverage all of these pressure points not only in perpetrating harassment, but also in retaliating against those who complain. See Nicole Porter, The Perils of Reporting Harassment, 71 StAN. L. ReV. OnLINE 49, 50 (2018) (citing "discipline, negative evaluations, department or shift changes, demotion [and] increased surveillance" as instruments of retaliation). 
the pre-existing dynamics that have left high-level harassment underreported and the laws against it underenforced. ${ }^{19}$ The \#MeToo movement appears to have tipped the balance, but thus far only in a subset of cases involving exclusively sexualized behavior. Employers who respond to the \#MeToo movement by looking solely at unwanted sexualized behavior are likely to miss the forest while uprooting particular trees. By contrast, examining the allocation of power in contemporary workplaces helps identify where and in what form sexual harassment is likely to occur. ${ }^{20}$ Not only are top-level employees uniquely situated to sexually harass their subordinates, their disproportionate influence and control makes any form of harassment, or any implicit threat of adverse consequences, more menacing.

Reports from judicial clerks of former Ninth Circuit Judge Alex Kozinski epitomize this dynamic. Absent context, the judge's alleged conduct - the occasional sexualized comment, display of pornography, or off-color joke over a period of thirty years - while inappropriate, would not likely be deemed severe or pervasive conduct actionable under antidiscrimination law. ${ }^{21}$ But the alleged events occurred in a relationship of the most extreme power imbalance, one in

19. See Estlund, supra note 17, at 351 ("Although retaliation against employees who assert their rights at work is usually unlawful, the law is far from swift or sure in its response."); Porter, supra note 18 , at 50 (" $[\mathrm{R}]$ eporting harassment is fraught with risk, and often brings very little reward.").

20. To be clear, this is not a causal argument. My claim is not that workplace power allocations are determinative of sexual harassment, but rather that attention to the inherent dynamics of at-will relationships reveals more subtle forms of sexual harassment, including non-sexualized harassment and sexualized behavior that might not otherwise be perceived as severe or pervasive. For a nuanced examination of the role of power and other causal factors in producing harassment, including a review of the sociological literature, see Joanna L. Grossman, The Culture of Compliance: The Final Triumph of Form Over Substance in Sexual Harassment Law, 26 HARV. WOMEN's L.J. 3, 35-37 (2003).

21. See Matt Zapotosky, Prominent Appeals Court Judge Alex Kozinski Accused of Sexual Misconduct, WASH. POST (Dec. 8, 2017), https://www.washingtonpost.com/world/national-security /prominent-appeals-court-judge-alex-kozinski-accused-of-sexual-misconduct/2017/12/o8/1 763e2b8-d913-11e7-a841-2066faf731ef_story.html [https://perma.cc/5CCT-7G94]. To be actionable, discriminatory harassment must be severe or pervasive. See generally Harris v. Forklift Sys., Inc., 510 U.S. 17, 21 (1993) (clarifying the standard for actionable sexual harassment under Title VII); Meritor Sav. Bank v. Vinson, 477 U.S. 57, 67 (1986) (recognizing sexual harassment as actionable sex discrimination where sufficiently extreme to affect terms and conditions of employment). Courts generally do not deem verbal statements severe, and the isolated nature of the judge's statements, which occurred from time to time over a period of years and were directed toward different clerks, would make it difficult for any one plaintiff to establish pervasiveness. See SANDRA F. SPERINo \& SuJA A. ThOMAS, UnEQUAL: How AmerICA's COURTS UNDERMINE DisCRIMINATION LAW 32-40 (2017) (critiquing these and related judicial interpretations of the sexual harassment standard for barring recovery to a disproportionate number of victims). 
which recent entrees to the legal profession work in isolation for a revered judge with a lifetime appointment to one of the most respected federal appeals courts in the country. They also unfolded in an environment where power was allegedly exploited in other nonsexualized ways - the judge calling his clerks "slaves," insisting on their absolute loyalty, and asserting total control over their lives and schedules. ${ }^{22}$ Such context colors the allegations to chilling effect and clarifies the appropriate inquiry. The question should not be whether the individual sexualized references were pervasive in and of themselves, but whether the entire climate created by the judge's behavior constituted a hostile environment for female clerks based on their sex. ${ }^{23}$

This description of workplace power dynamics may justify an aggressive response to allegations of sexual harassment against the type of high-level employees who have come under the \#MeToo spotlight. But the power dynamics play out differently in cases of harassment allegations leveled against lower-status employees. Isolated sexualized comments or actions by these workers, particularly those lacking supervisory authority, are comparatively less likely to create a toxic work environment because they are not accompanied by an implicit threat to impose work-related consequences on the victim. For the same reason, such rank-and-file workers are also less capable of leveraging workplace power dynamics to perpetrate nonsexualized gender-based harassment. ${ }^{24}$

Most critically, these workers share with their accusers a vulnerability to indiscriminate adverse action by those above them in the workplace hierarchy. The very dynamics that make workers susceptible to sexual harassment in the first place put them at risk of excessive disciplinary action in the face of sexual harassment allegations. Employers' absolute power, combined with their conflation of sex and sexual harassment, mean that in the \#MeToo-inspired race to root

22. Editorial, \#MeToo Makes Its Way to the Judiciary, WASH. Post (Dec. 23, 2017), https://www .washingtonpost.com/opinions/metoo-makes-it-way-to-the-judiciary/2017/12/23/488946d4 -e5d5-11e7-ab5o-621feo588340_story.html [https://perma.cc/4XF5-6D2L].

23. To be sure, one might worry about the ability of those in power to engage in such behavior vis-à-vis all workers, but such "equal opportunity harassment" is not proscribed by antidiscrimination law; indeed, it is protected by employment at will. For a discussion of the problem of generalized, non-discriminatory workplace bullying, the law's limitations in redressing it, and possible legislative solutions, see David Yamada, Crafting a Legislative Response to Workplace Bullying, 8 EMP. RTs. \& EMP. POL. J. 475 (2004).

24. That is not to say that supervisors are the only employees capable of creating a hostile work environment. Indeed, some studies suggest that co-worker harassment is more common than supervisory harassment. See Grossman, supra note 20, at 35-36 (reviewing the literature on this point). The point is that the victim's experience of sexualized behavior as hostile will be influenced by the status of the perpetrator. For an example of egregious sexual harassment perpetrated by male subordinates against their female supervisor, see Soucek, supra note 10, at $70-73$. 
out inappropriate sexualized behavior, workers with less power, engaged in less pernicious behavior, are likely to be swept up in the rush to judgment.

\section{LAW, PRIVATE ORDERING, AND THE CONSTRUCTION OF WORKPLACE POWER}

The above account of the baseline power allocations in the workplace illustrates the harm of harassment and its relationship to workplace hierarchy. But there is more to the story. Private ordering by employers, in response to the law and in furtherance of their business interests, exacerbates these pre-existing imbalances. Their choices directly affect whether an accused harasser is likely to receive fair treatment.

\section{A. Contractual Protection for the Top Dogs}

Top-level employees enjoy terms of employment far more favorable than those afforded to everyone else. In addition to generous compensation and benefits, these individuals often negotiate job-security rights that constrain employers' ability to terminate or discipline them even in situations involving alleged sexual harassment.

The terms of chief executive contracts provide a striking example. A 2006 study examining the contracts of 375 CEOs revealed that the overwhelming majority of agreements protect against arbitrary termination, either in the form of a guaranteed term of employment ("fixed-term" contracts), the right to lucrative payouts in the event of termination without cause, or a combination of the two. ${ }^{25}$ Most importantly, these agreements significantly limit employers' ability to act for "cause" by providing narrow, exclusive definitions of the term. Legitimate grounds for terminating executives are commonly restricted to instances of willful misconduct, moral turpitude, or failure to perform duties, ${ }^{26}$ categories understood to permit termination only in extreme situations. ${ }^{27}$ Egregious harassment could fall within some of these categories, but lesser misconduct, like that

25. Stewart J. Schwab \& Randall S. Thomas, An Empirical Analysis of CEO Employment Contracts: What Do Top Executives Bargain For?, 63 WASH. \& LEE L. REV. 231, 247 (2006).

26. Id. at 233. Even in situations where a fixed-term contract does not expressly enumerate grounds, courts generally apply a narrower definition of just cause than that applied to indefinite agreements, requiring employers to show a material breach by the employee as opposed to any business justification. See RESTATEMENT OF EMPLOYMENT LAW $\$ 2.04 \mathrm{cmt}$. b (AM. LAW. INST. 2015).

27. Executive employee exit is almost always a negotiated affair, resulting in a dearth of relevant caselaw. Those decisions that exist offer minimal protection and few answers to employers 
alleged against Judge Kozinski, likely would not. Only two contracts in the research sample explicitly permitted termination for sexual harassment. ${ }^{28}$ In short, adverse employer action taken in response to allegations of sexual harassment could, in many cases, subject companies to contractual liability.

The risk of liability is heightened by the employee-friendly standards of proof that often apply to written-contract disputes. In cases involving employees who lack power to obtain an individualized written contract, but who nonetheless can establish implied rights to long-term employment, the burden is on the employee to show that the employer's rationale was inadequate or pretextual. ${ }^{29}$ Courts give employers wide latitude in justifying termination decisions. It is often enough that the decision-maker reasonably and in good faith believed it had cause to remove the employee, even if in retrospect its decision proves incorrect. ${ }^{30}$ In contrast, where an employee is protected by a fixed-term contract, the employer must be able to demonstrate by a preponderance of the evidence that the underlying misconduct occurred. ${ }^{31}$ In other words, if employers wish to cleanly remove high-level employees based on sexual harassment, they better be right about what happened.

Employers must also attend to all procedural requirements set forth in the parties' agreement. Balles v. Babcock Power, Inc., a recent case involving a breach of contract action by a former executive, offers a cautionary tale about the risks of improvident termination. ${ }^{32}$ The plaintiff, Balles, began an affair with an intern under his supervision, which, while apparently consensual, violated numerous company policies. ${ }^{33}$ Owing to his influence, the company hired her, and over

navigating their legal rights in the face of high-level harassment. See Balles v. Babcock Power Inc., 70 N.E.3d 905, 916 (Mass. 2016) (holding an employer liable for breach of an executive's stock contract despite the executive's sexual misconduct where the company failed to provide notice and an opportunity for the executive to cure his behavior); Prozinski v. Ne. Real Estate Serv., 797 N.E.2d 415, 423-24 (Mass. App. Ct. 2003) (ruling that a question of fact existed as to whether an executive's pattern of harassing behavior against multiple women, combined with financial mismanagement, constituted material breach justifying the company's refusal to pay severance upon termination).

28. Schwab \& Thomas, supra note 25 .

29. See, e.g., Pugh v. See's Candies, 116 Cal. App. 3 d 311,329 (1981).

30. See, e.g., Cotran v. Rollins Hudig Hall Int'l, Inc., 948 P.2d 412, 423 (Cal. 1998) (finding that the jury should consider not whether Cotran actually sexually harassed other employees, but whether, at the time of termination, the decision to terminate his employment was made in good faith by the defendants).

31. Restatement OF EMPLOYMENT LAW $\$ 2.04 \mathrm{cmt}$. d (AM. LAW. INST. 2015).

32. Balles, 70 N.E.3d at 907 .

33. Id. at 909 . 
the course of their relationship, Balles, while continuing to serve as her supervisor, promoted and awarded her raises, traveled with her on company-funded trips, and sent her sexually explicit messages and photos through company devices. ${ }^{34}$

Upon discovering the relationship, the company terminated Balles, refused to pay him severance, and exercised an adverse provision in his stock agreement. ${ }^{35}$ Balles sued and won, successfully arguing that his behavior did not constitute cause permitting the employer to buy back his shares in the company. ${ }^{36}$ His stock agreement allowed the employer to exercise its rights upon "fraud, ... gross insubordination ... [or] willful and material breach ... not corrected within thirty" days. ${ }^{37}$ The court read the first two grounds narrowly, rejecting arguments that Balles's flouting of company policy and efforts to cover up his affair constituted either fraud or insubordination. ${ }^{38}$ More revealingly, it dismissed the theory that Balles's conduct might have constituted a material breach, owing to the company's failure to provide the requisite notice and opportunity to cure. ${ }^{39}$ In so doing, it rejected the employer's argument that Balles's abuse of power and the harm he had caused could not be undone. ${ }^{40}$ In effect, the court held that the executive was contractually entitled to one free bite at the apple. ${ }^{41}$

Balles illustrates why employers are inclined to be cautious in responding to allegations of harassment perpetrated by high-level employees. Not only are these individuals "just cause" employees, their contracts typically qualify that term to preclude termination for some behavior that would ordinarily appear to constitute cause-including inappropriate sexual behavior. Yet the \#MeToo movement has revealed a further twist: media sources report that Harvey Weinstein's contract not only limited permissible causes for termination to conviction of a crime or fraud, an exceedingly narrow definition even by executive-contract standards, but actually contemplated and permitted misconduct toward other

34. Id.

35. Id. at 909-10.

36. Id. at 918 . In contrast to the stock agreement, the employment agreement did not limit the grounds for termination, and consequently the trial court's finding that the company was not obligated to pay Balles severance under that agreement was not appealed. Id. at 910.

37. Id. at 908. The agreement also permitted termination in two other cases-commission of a felony or willful failure to perform - which the employer did not invoke in its defense.

38. Id. at 913-14.

39. Id.

40. Id. at 916 .

41. The plaintiff was ultimately awarded his stock less a withholding for the company's successful counterclaim for breach of fiduciary duty, a claim not dependent on any contract. Id. 
employees. If Weinstein "treated someone improperly in violation of the company's Code of Conduct," the contract required him to reimburse the company for any resulting settlements or judgments and pay a graduated penalty of between $\$ 250$,000 and one million dollars depending on the number of prior violations. ${ }^{42}$ Thus, the contract not only created a safe harbor for Weinstein's sexual misconduct, it anticipated and condoned an ongoing pattern of misbehavior, as long as Weinstein was willing to pay for the privilege.

One can hope that contracts like Weinstein's are a rarity. But they demonstrate the lengths to which companies will go to reward and protect the top dogs of their industry. It is one of the great achievements of the \#MeToo movement that the prospect of public censure is changing the calculus for employers regarding sexual harassment allegations against high-level executives. At least in some cases, taking action against harassers has become worth the financial and legal risk. But those risks remain substantial. The value of the lost dividends alone owed to the plaintiff in Balles was over $\$ 900,000$, far in excess of the damages cap on sexual harassment claims. ${ }^{43}$ In such situations, employers have more to lose in terminating the accused than in paying out on a claim for sexual harassment. Given how the deck is stacked, there is little reason to fear that employers will respond too harshly or act without evidence against high-level harassers.

\section{B. Employment at Will and the Powerless Harasser}

When the conduct of an ordinary employee is in question, however, employer incentives cut the opposite way. To be sure, lower-level employees, even those without supervisory authority, are capable of producing a hostile work environment, but such employees lack power vis-à-vis their employer. ${ }^{44}$ If an accused harasser is employed at will, companies have little to lose by terminating

42. Harvey Weinstein Contract with TWC Allowed for Sexual Harassment, TMZ (Oct. 12, 2017), http://www.tmz.com/2017/10/12/weinstein-contract-the-weinstein-company-sexual -harassment-firing-illegal [https://perma.cc/FH6U-ZVHH]. Media sources suggest that Fox News political commentator Bill O'Reilly was similarly insulated against repercussions for sexual harassment by a provision prohibiting termination for allegations of misconduct absent proof in court. Testimony: Bill O'Reilly Had a Contractual Provision Virtually Allowing Sexual Harassment, WASH. Post (Nov. 8, 2017), https://www.washingtonpost.com/blogs/erik -wemple/wp/2017/11/o8/testimony-bill-oreilly-had-a-contractual-provision-virtuallyallowing-sexual-harassment/?utm_term=.241d6eozac54 [https://perma.cc/R2MN-R86T].

43. Balles v. Babcock Power, Inc., No. MICV201004806, 2014 WL 10337843, at ${ }^{\star} 6$ (Mass. Super. Ct. 2014). Title VII caps compensatory and punitive damages at $\$ 300,000$ for employers with 500 employees or more. 42 U.S.C. $\$ 1981 a(b)(3)(D)$ (2012).

44. See supra note 24 and accompanying text. 
that individual, and every incentive to hedge against the risk of sexual harassment liability.

Weighing against accused harassers in this calculus is the law of sexual harassment itself, which places a premium on swift and decisive employer responses. The 1998 Supreme Court decisions in Burlington Industries, Inc. v. Ellerth and Farragher v. Boca Raton provide employers with an affirmative defense to vicarious liability for hostile work environment harassment perpetrated by a supervisor. ${ }^{45}$ To assert this defense, the employer must show that it "exercised reasonable care to prevent and correct promptly any sexually harassing behavior" and that the victim failed to take advantage of opportunities to avoid or end the harm. ${ }^{46}$ Scholars have criticized this defense as spawning human resource trainings and superficial policies that courts accept as evidence of preventive action but that are in fact largely ineffective in reducing sexual harassment. ${ }^{47}$

While most preventive action as currently implemented may be unhelpful to victims, the corrective action element is objectionable in a different way: Ellerth/Farragher-inspired corrective action can be excessively harmful to the accused. Corrective action generally involves investigating and redressing any report of objectionable behavior. Terminating an accused harasser is a surefire way of satisfying this element of the defense, even if the reported behavior might merit lesser discipline. In cases of uncertainty, as when the employer is unable to verify whether harassing conduct occurred, it is safer for employers to err on the side of punishing the accused. Even if the employer is mistaken, its actions are presumptively protected by the employment-at-will rule, whereas insufficient

45. Burlington Indus., Inc. v. Ellerth, 524 U.S. 742 (1998); Faragher v. Boca Raton, 524 U.S. 775 (1998).

46. Ellerth, 524 U.S. at 765 ; Faragher, 524 U.S. at 807 . In cases of coworker harassment, a negligence standard applies with the assessment often turning on similar considerations. See Vance v. Ball State Univ., 133 S. Ct. 2434, 2452 (2013) (noting that where harassment is commited by a nonsupervisor, a plaintiff can "prevail by showing [the] employer was negligent in failing to prevent harassment" and explaining that "[e]vidence that an employer did not monitor the workplace, failed to respond to complaints, failed to provide a system for registering complaints, or effectively discouraged complaints from being filed would be relevant"); Ellerth, 524 U.S. at 759 ("An employer is negligent with respect to sexual harassment if it knew or should have known about the conduct and failed to stop it.").

47. See, e.g., Susan Bisom-Rapp, Sex Harassment Training Must Change: The Case for Legal Incentives for Transformative Education and Prevention, 71 STAN. L. REV. ONLINE 62, 67-68, 70-71 (2018); Joanna L. Grossman, The Culture of Compliance: The Final Triumph of Form Over Substance in Sexual Harassment Law, 26 HARV. WoMEN's L.J. 3 (2003); Anne Lawton, Operating in an Empirical Vacuum: The Ellerth and Faragher Affirmative Defense, 13 COLUM. J. GENDER \& L. 197 (2004). 
responsive action in the face of credible allegations of harassment creates the risk of statutory liability. ${ }^{48}$

In this context, public calls for due process for accused harassers are ironic. There is no requirement of internal due process in an at-will workplace. If employers need no reason to terminate an employee, they need not verify the truth of the accusations underlying their decision, provide opportunities for the worker to be heard, or vet the proportionality of their response. In fact, harassers arguably get more due process than at-will employees who engage in any other form of misconduct, owing to their employers' efforts to protect themselves from victims' lawsuits. It is only because employers investigate allegations of harassment to avoid potential liability to the victim that those accused enjoy any form of process at all.

This legal landscape, combined with confusion over the underlying harm of sexual harassment, invites employers to enforce a broad, antisexual norm against vulnerable workers. ${ }^{49}$ My review of recent labor arbitration awards in union grievances bears this out. Labor awards are among the only available sources of adjudication of employer termination and discipline for employee misconduct, including sexual misconduct. Unionized employees, unlike most rank-and-file workers, are contractually entitled to job security and progressive discipline, a system of gradually escalating penalties for repeated infractions. ${ }^{50}$ Those subject to adverse treatment may challenge their employer's decision through a formal grievance process culminating in arbitration, in which the burden of proof falls to the employer to establish just cause. ${ }^{51}$

During the five-year period from January 1, 2013 through January 1, 2018, there were sixty-four reported labor arbitration awards involving discipline or termination based at least in part on alleged sexual harassment, inappropriate

48. Elizabeth Chuck, Accusations in the \#MeToo Era: How Companies Handle Complaints, NBC News (Dec. 17, 2017), http://www.nbcnews.com/storyline/sexual-misconduct/accusationsmetoo-era-how-companies-handle-complaints-n829326 [https://perma.cc/2KCZ-64ER]; Dana Wilkie, A Rush to Judgment? Are Companies and Politicians Reacting Too Quickly to Sexual Harassment Allegations?, Soc. For Hum. ResourCe MGMT. (Dec. 1, 2017), https://www.shrm .org/resourcesandtools/hr-topics/employee-relations/pages/sexual.aspx [https://perma.cc /F2CC-NPST].

49. Schultz's work is replete with examples. See Schultz, Sanitized Workplace, supra note 8, at 2087-90.

50. For a general explanation of the concepts of just cause and progressive discipline in the unionized workplace, including sample clauses and their prevalence, see BLOOMBERG BNA LABOR AgreEMENT IN NEgOtiation AND ARBITRATION 228-30 (2d ed. 1995); BLOOMBERG BNA, BASIC PATTERns In Union CONTRACTS 7 (14th ed. 1995).

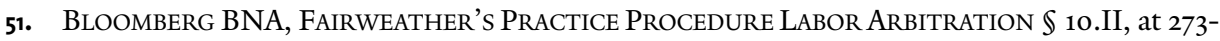
75 (4th ed. 2018). 
sexual behavior, sexual language or innuendo, bodily exposure, or sexually explicit material. ${ }^{52}$ In twenty-eight of the awards, the grievant prevailed, meaning the grievant obtained either a reversal or reduction in the employer's punishment. Thus, in nearly forty-five percent of awards, the arbitrator concluded that the employer had gone too far or acted without sufficient justification or process. $^{53}$

Several of these reversals exemplify the tendency of employers to engage in overzealous disciplinary action in response to behavior that relates to or invokes sex or sexuality, regardless of context. In one award, the grievant was a female distribution-center employee for a national retailer who was involved in a consensual domestic partnership with another female employee. ${ }^{54}$ Privately, the couple argued at work about the grievant's alleged romantic interest in another coworker, during which the grievant made a sexual comment about the coworker. ${ }^{55}$ The suspicious partner subsequently confronted the coworker and told her about the grievant's comment. ${ }^{56}$ The shocked coworker stated that she was straight and asked to be left out of the couple's problems. ${ }^{57}$ An HR investigation ensued, and the employer terminated both the grievant and her partner for violating the company's harassment policy. ${ }^{58}$

In another example, a male grievant, a supermarket meat cutter, was terminated for mooning his male coworker. ${ }^{59}$ The two were engaged in horseplay in a nonpublic area of the store when the coworker dared the grievant to drop his

52. This sample was obtained by reviewing all reported awards in Bloomberg BNA's Labor Arbitration Awards database during the relevant time period containing the term "sexual harassment." This yielded a body of 207 awards, of which sixty-five unique decisions were determined to be relevant.

53. Similar studies, conducted in 1999 and 2004, found grievances sustained at rates closer to fifty percent. Estelle D. Franklin, Maneuvering Through the Labyrinth: The Employers' Paradox in Responding to Hostile Environment Sexual Harassment-A Proposed Way Out, 67 FordHAM L. REV. 1517 (1998-1999); Margaret A. Lucero et al., Protecting the Rights of Alleged Sexual Harassment Perpetrators: Guidance from the Decisions of Labor Arbitrators, 16 EMP. RTS. \& RESP. J. 71 (2004).

54. Rite Aid of W. Va., Inc. v. Teamsters Local 175, 138 Lab. Arb. Rep. (BNA) 225, 226 (2017) (Wilson, Arb.).

55. Id.

56. Id.

57. Id.

58. Id.

59. United Food \& Commercial Workers Union Local v. Emp'r, 2016 Lab. Arb. Rep. (BNA) Supp. 200612 (2016) (Altman, Arb.). 
pants. The grievant briefly obliged and the coworker, without the grievant's permission, snapped a photo. ${ }^{60}$ Upon the grievant's objection, the coworker purported to delete the photo, but many months later, he showed it to another male employee who reported it to management. According to the grievant, the coworker displayed the photo to retaliate against him for reporting the coworker for taking excessive breaks. ${ }^{61}$ The employer investigated and terminated both employees. Defending its decision in the arbitration that followed, the employer likened the conduct to two instances of unwelcome male-on-female genital exposure that had led to termination. ${ }^{62}$

Examples like these suggest that the risk of disproportionate discipline against rank-and-file workers is real. Neither award involved an abuse of power; both involved actions by coworkers who were not in a supervisory relationship. In neither case did the objectionable conduct reflect hostility toward or disparate treatment of the "victim" based on sex. The employee who reported the photo in the horseplay case stated he did not find it offensive. ${ }^{63}$ The comment in the warehouse case was the product of a domestic argument and was not based on sex discrimination.

If anything, the terminations appear to have endorsed rather than penalized opportunistic, possibly even discriminatory, behavior. The fact that the comment in the warehouse was made by a lesbian woman referencing lesbian sex may have contributed to the straight worker's reaction, heightening its perceived offensiveness. ${ }^{64}$ In the horseplay case, the photo-snapping coworker turned an inoffensive, if inappropriate, jest between workplace friends into a sanctionable act of public exposure, allegedly to get even with the grievant in a petty dispute.

Most disturbing of all is that these terminations happened prior to \# MeToo in unionized workplaces where employers are accountable for their personnel decisions. Employers enjoying the freedom of an at-will workplace, responding to the public pressures of the movement, are likely to act even more aggressively in disciplining sexualized conduct.

6o. Id.

61. Id.

62. Id. The just cause standard applicable in grievance proceedings requires the employer to prove, among other things, that the grievant received "equal treatment" vis-a-vis others who committed similar offenses in the past. See Bloomberg BNA, Just Cause: THe Seven Tests vii-viii (3d ed. 2006) [hereinafter SEVEN TESTS]; see also infra note 69 and accompanying text.

63. Id. Under Meritor, sexual harassment, to be actionable, must be "unwelcome," or in the Court's subsequent articulation of the claim, it should be subjectively offensive to the victim. Meritor Sav. Bank v. Vinson, 477 U.S. 57, 68 (1986); Harris v. Forklift Sys., Inc., 510 U.S. 17, 22 (1993).

64. See Schultz, Sanitized Workplace, supra note 8, at 2158-63 (suggesting allegations of harassment are more likely to be leveled at sexual minorities and nonwhite workers). 


\section{FAIR TERMS, FAIR PROCESS: ACCOUNTABILITY DESPITE PRIVATE ORDERING}

How should employers handle sexual harassment accusations? This Essay has suggested that the risks of disproportionate employer responses to harassment allegations cut in different directions depending on the employment status of the accused. A reallocation of workplace power would, of course, do much to remedy the situation. If workers had greater job security and greater voice in determining their working conditions, they would be less vulnerable both to workplace harassment and to overzealous discipline following harassment allegations. It would also be more difficult for employers to terminate them, marginalize them, or purchase their silence in an effort to retain and protect highlevel harassers. ${ }^{65}$

Of course, imaging a fundamental restructuring of the workplace and employment at will is beyond the scope of this Essay. Terms and duration of employment are, and for the foreseeable future will continue to be, the province of private ordering. Fortunately, the outpouring of support for the \#MeToo movement and the responsive action taken thus far suggest that employers are currently amenable to self-directed change. The time is ripe for proposals. What follows are initial suggestions for how employers might rethink their contracting practices and disciplinary protocols to achieve more just results when dealing with harassment allegations.

To begin, employers should keep doing what they have begun doing in light of \# MeToo: terminating or otherwise holding harassers accountable, even if it means unseating an iconic or revered person and even if there is a financial cost to doing so. There is also much that employers can do proactively with respect to their contracts with top-level employees. Employment agreements that confer job security should define "cause to terminate" to include conduct reasonably likely in itself, or in tandem with further comparable behavior, to violate antidiscrimination laws. ${ }^{66}$ To be sure, top-level employees will push to limit employer discretion and foreclose the possibility of termination for isolated or seemingly

65. On the problem of confidentiality and settlement practices in connection with \#MeToo, see Ian Ayres, Targeting Repeat Offender NDAs, 71 STAN. L. REV. ONLINE 76 (2018) (arguing for a middle-ground approach to enforceability of nondisclosure provisions in sexual harassment settlement agreements that would respect victims' and perpetrators' preference for private resolution but ensure public access to information about the dispute in the event that the perpetrator re-offends).

66. This would disrupt the current incentive scheme by giving employers more flexibility to terminate high-level employees for sexual harassment despite uncertainty as to whether the perpetrator's behavior would ultimately satisfy the "severe or pervasive" standard. 
trivial misconduct, and many have the bargaining power to insist on such terms. But a candidate's resistance to a provision specifically invoking compliance with antidiscrimination laws is a signal that companies should heed. In short, employers should not agree to contract terms that have the effect of insulating highlevel employees from the consequences of sexual harassment or of sanctioning repeat offenses. Provisions like those allegedly contained in Harvey Weinstein's contract should become a thing of the past, and any that exist should be deemed voidable in contravention of public policy. ${ }^{67}$

Employers should also develop counterincentives to sexual harassment. Executives and high-level managers are typically rewarded based upon stock performance and other financial benchmarks. Employers might consider rewarding these employees on such bases as the promotion of women and minorities, efforts to equalize pay, and reductions in Equal Employment Opportunity Commission filings. ${ }^{68}$

For all other employees, who have no contract protections and no bargaining power, employers should adopt a proportionate discipline protocol. The union grievance process provides a template. The evaluation of whether an employer terminated an employee for just cause for grievance purposes commonly involves a seven-part test that focuses on three basic areas: the wrongdoing of the employee, the quality of the employer's investigation, and the appropriateness

67. Basic contract law provides that contract terms may be voided as a matter of public policy, despite the assent of both parties, where the law's interest in enforcing the terms is outweighed by the public's interest in non-enforcement. See RESTATEMENT (SECOND) OF CONTRACTS $\ 178$ (AM. LAW INST. 1981). Job-security provisions that protect harassers are not themselves unlawful, but to the extent they discourage employers from taking appropriate steps to prevent or correct harassment, their enforcement runs contrary to the public interest embodied in antidiscrimination laws. This theory has already been adopted by courts in the context of sexual harassment settlement agreements that preclude victims from filing charges or cooperating with the Equal Employment Opportunity Commission (EEOC). See EEOC v. Astra USA, Inc., 94 F.3d 738, 744-45 (1st Cir. 1996) (finding that enforcement of such provisions would unduly hamper the EEOC's ability to investigate and curtail harassment in vindication of the public interest, and that such concerns outweighed any value served by such provisions in enabling private dispute settlement).

68. Cf. Tristin Green, Discrimination in Workplace Dynamics: Toward a Structural Account of Disparate Treatment Theory, 38 HARV. C.R.-C.L. L. REV. 91, 146-48 (2003) (advancing a theory of disparate treatment law that links employer liability with the adoption of institutional safeguards to counteract implicit bias and stereotyping); Schultz, Sanitized Workplace, supra note 8, at 2174-76 (advocating for litigation advantages to employers who meet gender desegregation benchmarks). 
of the employer's adverse action judged in the context of the particular workplace. ${ }^{69}$ This inquiry can inform an employer's determination of what constitutes a proportionate response in the context of alleged sexual harassment.

In the grievance context, arbitrators assess the employee's wrongdoing in relation to the employer's rules. ${ }^{70}$ In the harassment context, employers should assess wrongdoing with an informed understanding of what sexual harassment is and why it is harmful. That is, they should ask whether the conduct was harassing to members of one sex and exploitive of workplace power dynamics. In evaluating the investigation, labor arbitrators ask whether the process was thorough and fair and supported the employer's conclusions. ${ }^{71}$ This evaluation includes determining such things as whether the employer interviewed all available witnesses, engaged in appropriate follow up, provided the accused notice and an opportunity to be heard, and reached its ultimate decision objectively and deliberatively. ${ }^{72}$ Employers should bear in mind the same considerations when investigating harassment, mindful that the facts in dispute often concern the perpetrator's underlying intent and the victim's genuine perception rather than whether the complained-of behavior actually occurred. Consistent with sexual harassment law, employers should ask whether the conduct was offensive to the victim and likely to be offensive to members of the victim's sex. ${ }^{73}$

Finally, in assessing the appropriateness of disciplinary action, arbitrators ask whether the punishment fit the crime. In sexual harassment matters, employers should not treat offensive statements, particularly isolated ones, the way they would treat recurring or unwelcome physical conduct. In such instances, corrective action short of termination may provide a tailored and effective response. In addition to proportionality considerations, the inquiry invites self-examination on the employer's part. In the grievance context, arbitrators take account of mitigating circumstances, including employer practices and whether it may have condoned or contributed to the employee's conduct. ${ }^{74}$ This is not to suggest that known perpetrators should escape punishment, but rather that organizations must be careful not to scapegoat individual actors at the expense of broader cor-

69. Known commonly as the "seven tests," the questions are attributed to Arbitrator Carroll Daugherty's decision in Enterprise Wire Co., 46 Lab. Arb. Rep. (BNA) 359 (1966) (Daugherty, Arb.). See SEVEN TESTS, supra note 62, at 27-28.

70. Id. at 11-12.

71. Id. at 265 .

72. See SEVEn TeSTS, supra note 62, at 185-214, $265-74$.

73. Harris v. Forklift Sys., Inc., 510 U.S. 17, 22 (1993).

74. SEVEn TESTS, supra note 62, at 463-64. 
rective action. As Schultz's work has shown, sexual harassment flourishes alongside other forms of gender inequality. ${ }^{75}$ Employers should not ask merely whether the employee's conduct merited a particular response, but whether their own conduct deserves censure. What has the employer done to advance women's careers, improve their working conditions, create cultures of inclusion, and ensure equal opportunity? Such questions are far more important than ferreting out sexual conduct by low-level employees, an endeavor that can seem like an easy solution but in reality can divert attention away from institutional responsibility. ${ }^{76}$ Systemic changes within organizations can have broader and more far-reaching impact in achieving gender equality than one-off punishments of low-level harassers. Employers should view the quest to end harassment not as a witch hunt, but as a process of institutional self-reflection.

\section{CONCLUSION}

The \#MeToo movement has exposed outrageous, even criminal, conduct by the masters of the workplace, revealing not just a tendency to odious behavior at the top of organizational hierarchies, but an extreme power imbalance in the workplace. Victims' accounts arising out of the \#MeToo movement reveal a world in which high-level decision makers wield unrestricted control over employees. Meanwhile, the organizations in which they work have looked away, even in situations of the most egregious abuse.

Amazingly, this state of affairs is changing. Women are speaking out; and just as importantly, they are being believed. At this momentous time, it may seem insensitive or even dangerous to ask about what happens to the accused. But in the end, harassers' rights are also workers' rights. Organizational structures that allow individual decision makers free reign to mete out the harshest forms of discipline are the same ones that enable harassers to leverage sexual harassment as means of asserting control over dependent workers. Achieving a calibrated organizational response to sexual harassment allegations may ultimately better serve the broader goals of the movement. Why not make the most of \# MeToo-for women and for all vulnerable workers?

75. Schultz, Reconceptualizing, supra note 8 .

76. On the limits and dangers of employer efforts to address sexual harassment through penalizing individual actors, see Anne Lawton, The Bad Apple Theory in Sexual Harassment Law, 13 GEO. MASON L. REV. 817, 836-37; (2005); Schultz, Sanitized Workplace, supra note 8, at 210319 . 
Chauncey Wilson Memorial Research Professor \& Director, Workplace Law Program, University of Denver, Sturm College of Law; B.A., Rutgers University; J.D. Harvard Law School; LL.M., Temple Law School. Many thanks to members of UNLEASH (United Legal Educators Against Sexual Harassment) Equality, including Susan Bisom-Rapp, Tristin Green, Rebecca Lee, Ann McGinley, Angela Onwuachi-Willig, Nicole Porter, Vicki Schultz, and Brian Soucek; the Colorado Employment Law Faculty (CELF) Scholarship Group, including Melissa Hart, Jose "Beto" Juarez, Martin Katz, Helen Norton, Nantiya Ruan, and Catherine Smith; and the Workplace Law Writing Collaborative, including Orly Lobel, Camille Gear Rich, Leticia Saucedo, and Michelle Travis. I am grateful for the research assistance of Callie Borgmann, J. Kirk McGill, Michelle Primo, and Ashley Smith-Roberts.

Preferred Citation: Rachel Arnow-Richman, Of Power and Process: Handling Harassers in an At-Will World, 128 YALE L.J.F. 85 (2018), https://www .yalelawjournal.org/forum/of-power-and-process. 